\title{
PENGEMBANGAN MEDIA PEMBELAJARAN ASAM BASA MENGGUNAKAN APLIKASI ANDROID BERBASIS \\ CHEMISTRY TRIANGLE KELAS XI SMA/MA
}

$$
\text { JURNAL }
$$

Sebagai Salah Satu Persyaratan Guna Memperoleh Gelar Sarjana Pendidikan

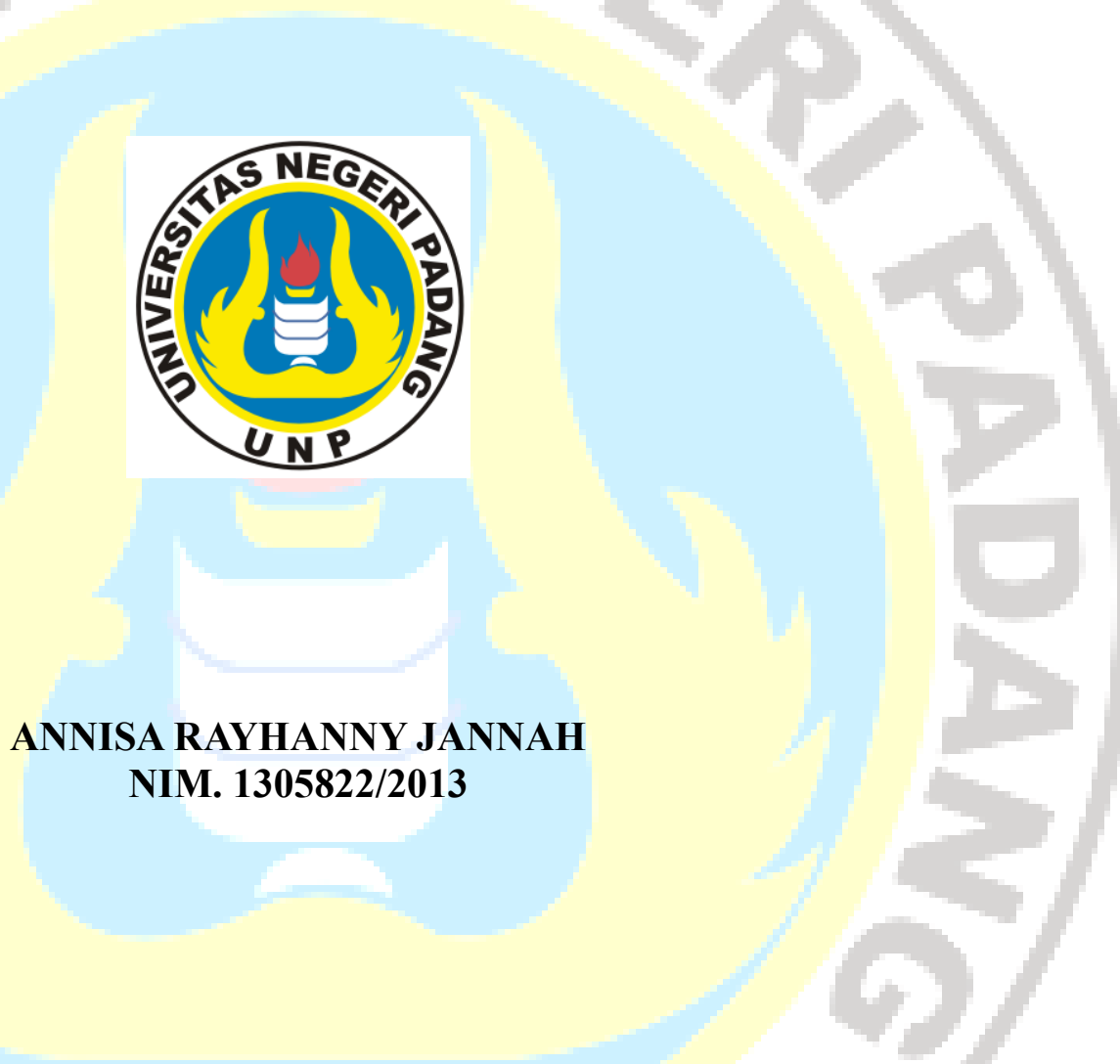

PROGRAM STUDI PENDIDIKAN KIMIA

JURUSAN KIMIA

FAKULTAS MATEMATIKA DAN ILMU PENGETAHUAN ALAM

UNIVERSITAS NEGERI PADANG 
PERSETUJUAN PEMBIMBING ARTIKEL E-JOURNAL

PENGEMBANGAN MEDIA PEMBELAJARAN ASAM BASA

MENGGUNAKAN APLIKASI ANDROID BERBASIS

CHEMISTRY TRIANGLE KELAS XI SMA/MA

\section{ANNISA RAYHANNY JANNAH}

Artikel dengan judul di atas telah kami setujui untuk dipublikasikan di e-journal dengan keterangan :

1. Artikel ini disusun berdasarkan skripsi saudara Annisa Rayhanny Jannah untuk persyaratan wisuda periode 108 dan telah diperiksa/disetujui oleh kami kedua pembimbingnya.

2. Nama dan urutan nama penulis dalam artikel ini adalah:

Annisa Rayhanny Jannah" ${ }^{\# 1}$ Rahadian $^{\# 2}$ Zul Afkar $^{\# 3}$

Padang, Februari 2017

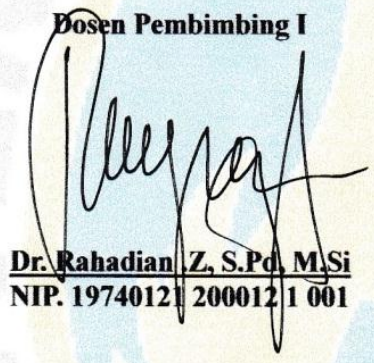

Dosen Pembimbing II

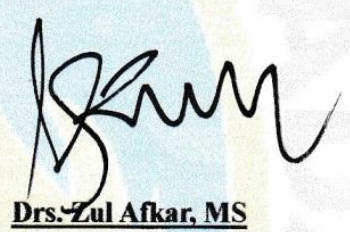

NIP. 195110291977101001 


\title{
PENGEMBANGAN MEDIA PEMBELAJARAN ASAM BASA MENGGUNAKAN APLIKASI ANDROID BERBASIS CHEMISTRY TRIANGLE KELAS XI SMA/MA Annisa Rayhanny Jannah"1 $\operatorname{Rahadian}^{\# 2}$ Zul Afkar $^{\# 3}$ Jurusan Kimia, Universitas Negeri Padang, Indonesia \\ ${ }^{\# 1}$ Mahasiswa Kimia, ${ }^{\# 2}$ Pembimbing I, ${ }^{\# 3}$ Pembimbing II annisa.rayhanny@gmail.com
}

\begin{abstract}
The aims of the research are to produce instructional media on acid-base using android app based chemistry triangle which practical and valid. The study can be categorized as Research and Development. The development of instructional media was carried out by adapting 4-D (four D models). The instruments used were validity sheet and practicality sheet. The validity sheet was filled by 5 chemistry lecturers and 2 chemistry teachers. And the practicality sheet filled by 4 chemistry teachers and 26 students of SMA Adabiah Padang. The questionnaires were analyzed using Cohens's kappa. The results of the validity, received mean value 0,83 and categories as "very high validity". The result of the practicality have mean value by the teachers 0,84 and by the students 0,88 and categories as "very high practicality". Based on the result can be concluded that instructional media on acid-base using android app based chemistry triangle of XI grade students in Senior High School very practical and valid to be used as a instructional media.
\end{abstract}

Keywords: instructional media, android, chemistry triangle, acid-base, 4-D models, Cohen's kappa.

\section{PENDAHULUAN}

Asam Basa adalah materi yang dipelajari oleh siswa di kelas XI semester II. Pada materi asam basa peserta didik dituntut untuk dapat mendeskripsikan teoriteori asam basa dan menentukan $\mathrm{pH}$ suatu larutan dengan perhitungan.

Berdasarkan hasil wawancara dengan 5 orang guru kimia di SMAN 12 Padang, SMAN 13 Padang, dan SMA Adabiah Padang, materi asam basa diajarkan dengan metode ceramah, diskusi dan eksperimen (praktikum) menggunakan buku teks dan lembar kerja siswa. Penyampaian materi hanya dilakukan secara verbal. Penyampaian materi secara verbal, membuat siswa hanya dapat menyebutkan kata tetapi tidak mengetahui artinya. ${ }^{[1]}$ Menurut Sunyono, pembelajaran kimia pada dasarnya merupakan pembelajaran yang sebagian besar topik-topik pembahasannya bersifat abstrak dan perlu pemahaman pada level submikroskopis. ${ }^{[2]}$

Menurut Chittleborough, di dalam Chemistry Triangle terdapat tiga level representasi yaitu level makroskopik, level sub-mikroskopik dan level simbolik ${ }^{[3]}$ Menurut Talanguer, level makroskopik merupakan representasi kimia yang diperoleh melalui pengamatan nyata terhadap suatu fenomena yang dapat dilihat dan dirasakan oleh panca indera. Level submikroskopik menyangkut susunan dan struktur dari partikel penyusun materi (molekul, atom, ion) beserta perubahannya. Level simbolik yaitu representasi kimia secara kualitatif dan kuantitatif. Hal Ini dapat membantu siswa lebih memahami materi-materi yang bersifat abstrak. Materi yang bersifat abstrak dapat digambarkan melalui media pembelajaran. Pemakai media juga dapat membangkitkan keinginan dan

Pembuatan media pembelajaran menggunakan aplikasi android telah dilakukan oleh Anggi Yanuariska (2015) dengan judul "Pengembangan Media Pembelajaran Kimia Berbasis Chemistry Triangle Menggunakan Aplikasi Android untuk Materi Elektrokimia Kelas XII SMA/MA”. minat yang baru, membangkitkan motivasi dan rangsangan kegiatan belajar. ${ }^{[5]}$

Perkembangan pesat di bidang teknologi khususnya teknologi informasi dan komunikasi telah membawa perubahan yang besar dalam berbagai bidang, termasuk di dalam dunia pendidikan. Dalam dunia pendidikan, perkembangan teknologi dapat dimanfaatkan untuk mendukung perkembangan pembelajaran mandiri jarak jauh, terutama dengan mengedepankan kemudahan, fleksibilitas dan interaktivitas antar pengguna.

Smartphone berbasis android adalah telepon genggam yang mempunyai kemampuan dengan penggunaan dan fungsi yang menyerupai komputer dengan sistem operasi berbasis linux. Smartphone berbasis android ini digunakan oleh hampir semua kalangan masyarakat terutama di kalangan remaja. Menurut hasil wawancara dengan 40 oarang siswa kelas XI di beberapa SMA kota Padang (SMAN 5 Padang, SMAN 12 Padang dan SMA Adabiah) rata-rata sudah menggunakan smartphone berbasis android. Namun, perangkat ini hanya digunakan oleh siswa untuk SMS (Short Message Service), telepon, chatting, internet dan hiburan seperti permainan dan musik. Disisi lain, smartphone sedang di kembangkan untuk pembelajaran. Salah satu pembelajaran yang memanfaatkan smartphone adalah media pembelajaran menggunakan aplikasi android.

Media pembelajaran menggunakan smartphone berbasis android ini dapat digunakan dalam belajar mandiri oleh siswa, sehingga siswa dapat belajar dimana saja dengan kecepatan belajar yang bisa disesuaikan dengan kemampuan masing-masing. Media ini juda dapat membantu guru dalam menyampaikan materi yang bersifat abstrak, khususnya dalam pembelajaran kimia.

Dari penelitian ini menyatakan bahwa media pembelajaran menggunakan aplikasi android layak digunakan sebagai media pembelajaran. ${ }^{[6]}$

Berdasarkan latar belakang di atas, penulis tertarik melakukan penelitian dengan merancang dan membuat 
media pembelajaran menggunakan aplikasi android pada materi asam basa untuk kelas XI SMA dengan judul "Pengembangan Media Pembelajaran Asam Basa Menggunakan Aplikasi Android Berbasis Chemistry Triangle Kelas XI SMA/MA.

\section{METODE PENELITIAN}

Jenis penelitian yang digunakan adalah Research and Development (R\&D), yaitu penelitian yang menghasilkan produk tertentu. Subjek penelitian ini adalah dosen jurusan kimia FMIPAUNP, guru kimia SMA, dan siswa kelas XI SMA Adabiah Padang. Objek penelitian ini adalah media pembelajaran asam basa menggunakan aplikasi android berbasis chemistry triangle kelas XI SMA/MA. Model pengembangan yang digunakan adalah model 4-D (Four D models). Model 4-D ini terdiri dari 4 tahap utama, yaitu: (1) pendefinisian (define), (2) perancangan (design), (3) pengembangan (develop) dan (4) penyebaran (disseminate) ${ }^{[7]}$. Pelaksanaan penelitian dimulai dari tahap define. Langkah-langkah pada tahap define ini meliputi analisis ujung depan, analisis siswa, analisis tugas, analisis konsep dan analisis tujuan pembelajaran. Tahapan yang kedua yaitu design. Pada tahapan desain yang dilakukan yaitu merancang media pembelajaran asam basa menggunakan aplikasi android berbasis chemistry triangle. Tahapan yang ketiga yaitu tahapan develop. Tahap ini terdiri dari tiga langkah, yaitu uji validitas, revisi, dan uji praktikalitas. Tahapan yang keempat yaitu tahapan disseminate atau penyebaran. Pada konteks pengembangan media pembelajaran, peneliti pada tahap disseminate ini membatasi hanya sampai tahapan sosialisasi media pembelajaran melalui pendistribusian dalam jumlah terbatas kepada guru. Pendistribusian ini dimaksudkan untuk memperoleh respons, umpan balik terhadap media pembelajaran yang dikembangkan. Apabila respon sasaran, penggun media pembelajaran sudah baik, maka baru dilakukan pencetakan dalam jumlah banyak dan pemasaran supaya media pembelajaran tersebut dapat digunakan oleh sasaran yang lebih luas. Namun, peneliti tidak melakukan pencetakan dalam jumlah banyak dan pemasaran karena keterbatasan waktu dan biaya.

Instrumen yang digunakan dalam penelitian ini adalah lembar validasi (ditujukan kepada dosen Kimia FMIPA UNP dan guru kimia) dan angket (terdiri dari angket respon guru dan siswa). Lembar validasi digunakan untuk menilai media pembelajaran dari segi komponen isi, komponen penyajian, komponen kebahasaan, dan komponen kegrafisan. Angket bertujuan untuk mengetahui tingkat praktikalitas pemakaian media pembelajaran. Teknis analisis data yang digunakan untuk analisis validitas, analisis kepraktisan (angket respon guru dan siswa) yaitu dengan menggunakan moment kappa $(\mathrm{k})^{[8]}$.

$$
\text { moment kappa }(k)=\frac{P-P e}{1-P e}
$$

Keterangan:

$\mathrm{k}=$ moment kappa yang menunjukkan validitas produk

$\mathrm{P}=$ Proporsi yang terealisasi, dihitung dengan cara jumlah nilai yang diberi oleh validator dibagi jumlah nilai maksimal

$\mathrm{Pe}=$ Proporsi yang tidak terealisasi, dihitung dengan cara jumlah nilai maksimal dikurangi dengan jumlah nilai total yang diberi oleh validator dibagi jumlah nilai maksimal

Tabel 1.Kategori Keputusan berdasarkan moment Kappa

\begin{tabular}{|cc|}
\hline Interval & Kategori \\
\hline $\mathbf{0 , 8 1}-\mathbf{1 , 0 0}$ & sangat tinggi \\
\hline $\mathbf{0 , 6 1}-\mathbf{0 , 8 0}$ & Tinggi \\
\hline $\mathbf{0 , 4 1}-\mathbf{0 , 6 0}$ & Sedang \\
\hline $\mathbf{0 , 2 1}-\mathbf{0 , 4 0}$ & Rendah \\
\hline $\mathbf{0 , 0 1}-\mathbf{0 , 2 0}$ & sangat rendah \\
\hline$<\mathbf{0 , 0 0}$ & tidak valid \\
\hline
\end{tabular}

\section{HASIL DAN PEMBAHASAN}

\section{A. Hasil Penelitian}

Berdasarkan tujuan dan prosedur penelitian yang telah dilakukan, maka dihasilkan media pembelajaran asam basa menggunakan aplikasi android berbasis chemistry triangle. Penelitian ini dirancang menggunakan model pengembangan perangkat pembelajaran 4-D, yaitu dengan tahap-tahap sebagai berikut ini.

\section{Tahap pendefinisian (define)}

Pada tahap define dilakukan penetapan dan pendefinisian syarat-syarat pembelajaran. Langkah-langkah pada tahap define ini meliputi: a) Analisis ujung depan. Analisis ujung depan ini bertujuan untuk memunculkan dan menetapkan masalah dasar yang dihadapi guru dan siswa dalam pembelajaran kimia. Berdasarkan analisis ini diketahui pada proses pembelajaran terutama pada materi asam basa diajarkan dengan metode ceramah, diskusi dan eksperimen (praktikum) menggunakan buku teks dan lembar kerja siswa. Untuk penggunaan media masih sedikit terkendala dengan jumlah infocus yang masih kurang. Penggunaan media tersebut menjadikan komunikasi antara guru dan siswa bersifat verbal. Selanjutnya analisis ujung depan juga dilakukan dengan mewawancarai 40 orang siswa kelas XI IPA tentang penggunaan smartphone berbasis android. Berdasarkan hasil wawancara yang dilakukan dengan siswa kelas XI SMAN 12, SMAN 13 dan SMA Adabiah Padang, kebanyakan dari mereka menyatakan mempunyai smartphone berbasis android. Namun, perangkat ini hanya digunakan untuk SMS (Short 
Message Service), telepon, chatting, internet dan hiburan seperti permainan dan musik. Di sisi lain, pemanfaatan smartphone untuk belajar diluar jam sekolah masih minim digunakan terutama dalam pelajaran kimia. b) Analisis siswa yaitu untuk menelaah karakteristik siswa sebagai gambaran untuk mendesain media pembelajaran. Kemampuan akademis siswa pada materi asam basa bersifat heterogen. Artinya ada siswa yang mempunyai kemampuan akademis tinggi, sedang dan rendah, siswa lebih menyukai pembelajaran dengan menggunakan media pembelajaran yang menarik dan menggunakan gambar dan siswa mudah lupa terhadap konsep yang dipelajari, jika guru hanya menjelaskan materi tersebut secara verbal. c) Analisis tugas yaitu menganalisis Kompetensi Inti (KI), Kompetensi Dasar (KD), dan materi pokok sehingga indikator pembelajaran dapat dirumuskan. Materi pokok asam basa tercakup pada kompetensi dasar KD 3.10 yakni peserta didik dapat menganalisis sifat larutan berdasarkan konsep asam basa dan/atau pH larutan. d) Analisis konsep. Analisis konsep merupakan identifikasi konsep-konsep utama pada materi yang akan dibahas. Konsep utama yang akan dibahas adalah materi asam basa. Adapun konsep utama yang teridentifikasi antara teori asam basa, indikator, asam kuat dan asam lebah serta perhitungan pH. e) Analisis tujuan pembelajaran. Berdasarksn analisis tugas dan analisis konsep maka dapat dirumuskan tujuan pembelajaran. Analisis ini dijadikan dasar untuk mengkonstruksi media pembelajaran yang dikembangkan. Adapun tujuan pembelajaran tersebut adalah sebagai berikut: 1) Peserta didik dapat mendefenisikan pengertian asam menurut Arrhenius dengan benar melalui video yang disajikan 2) Peserta didik dapat mendefenisikan pengertian basa menurut Arrhenius dengan benar melalui video yang disajikan 3) Peserta didik dapat mendefenisikan pengertian asam menurut Bronsted-Lowry dengan benar melalui video yang disajikan 4) Peserta didik dapat mendefenisikan pengertian basa menurut Bronsted-Lowry dengan benar melalui video yang disajikan 5) Peserta didik dapat menentukan asam konjugasi dengan tepat melalui video yang disajikan 6) Peserta didik dapat menentukan basa konjugasi dengan tepat melalui video yang disajikan. 7) Peserta didik dapat mendefenisikan pengertian asam menurut Lewis dengan benar melalui gambar yang disajikan 8) Peserta didik dapat mendefenisikan pengertian basa menurut Lewis dengan benar melalui gambar yang disajikan 9) Peserta didik dapat menentukan sifat suatu larutan menggunakan kertas lakmus dengan teliti melalui video yang disajikan 10) Peserta didik dapat menentukan sifat suatu larutan menggunakan kertas $\mathrm{pH}$ universal dengan teliti melalui video yang disajikan 11) Peserta didik dapat membedakan antara asam lemah dan asam kuat dengan tepat melalui video yang disajikan 12) Peserta didik dapat menghitung $\mathrm{pH}$ larutan asam jika diketahui konsentrasinya dengan teliti melalui video yang diberikan 13) Peserta didik dapat menghitung $\mathrm{pH}$ larutan asam lemah apabila harga $\mathrm{K}_{\mathrm{a}}$ diketahui dengan teliti 14) Peserta didik dapat membedakan antara basa lemah dan basa kuat dengan tepat melalui video yang disajikan 15) Peserta didik dapat menghitung $\mathrm{pH}$ larutan basa kuat jika diketahui konsentrasinya 16) Peserta didik dapat menghitung $\mathrm{pH}$ larutan basa lemah apabila harga $\mathrm{K}_{\mathrm{b}}$ diketahui.

\section{Tahap Perancangan (Design)}

Pada tahap ini dihasilkan rancangan media pembelajaran asam basa menggunakan aplikasi android berbasis chemistry triangle. Media ini dirancang berdasarkan tujuan pembelajaran yang akan dicapai. Media pembelajaran dibuat agar siswa dapat belajar secara mandiri diluar jam pelajaran sekolah baik untuk mengulang pelajaran maupun untuk mempelajari materi sebelum di berikan oleh guru. Media ini juga bertujuan menimbulkan motivasi siswa untuk belajar dan memberikan rasa praktis karena tidak perlu membawa buku kemana-mana tetapi tetap bisa belajar dengan smartphone mereka.

Materi yang biasanya disajikan dengan kalimat dan paragraf sehingga membuat siswa bosan untuk mempelajarinya. Untuk menghindari hal itu materi dalam media disajikan dengan beberapa video dan pertanyaan yang di harapkan dapat mengarahkan siswa menemukan konsep asam basa. Beberapa video disajikan dengan tiga level representasi, agar siswa dapat lebih mudah memahami materi sehingga dapat mencapai tujuan pembelajaran.

\section{Pengembangan (Develop)}

Tahap develop ini bertujuan untuk menghasilkan media pembelajaran asam basa menggunakan aplikasi android berbasis chemistry triangle yang valid dan praktis, sehingga didapatkan suatu perangkat yang dapat digunakan dalam belajar.

a. Uji Validitas Media Pembelajaran

Media pembelajaran asam basa menggunakan aplikasi android berbasis chemistry triangle yang telah selesai dibuat, kemudian divalidasi oleh validator. Penilaian media pembelajaran asam basa menggunakan aplikasi android berbasis chemistry triangle dilakukan dengan menggunakan lembar validasi yang dilakukan oleh 7 orang validator. Data validasi media pembelajaran ini diperoleh dari penilaian lima orang dosen jurusan kimia dan dua orang guru kimia SMA N 5 Padang. Hasil dari validasi dapat di lihat pada Tabel 2. 
Tabel 2. Hasil penilain validitas LKS oleh validator

\begin{tabular}{|c|l|c|c|}
\hline No. & \multicolumn{1}{|c|}{ Aspek yang Dinilai } & $\begin{array}{c}\text { Rata- } \\
\text { rata } \\
\text { nilai k }\end{array}$ & $\begin{array}{c}\text { Kategori } \\
\text { Kevalidan }\end{array}$ \\
\hline 1. & Komponen Isi & 0.82 & Sangat Tinggi \\
\hline 2. & Komponen Penyajian & 0.82 & Sangat Tinggi \\
\hline 3. & Komponen Kebahasaan & 0.82 & Sangat Tinggi \\
\hline 4. & Komponen Kegrafikan & 0.85 & Sangat Tinggi \\
\hline & Rata- Rata & 0.82 & Sangat Tinggi \\
\hline
\end{tabular}

Berdasarkan hasil validasi ahli terhadap media pembelajaran asam basa menggunakan aplikasi android berbasis chemistry triangle diperoleh analisis validasi media pembeljaran sudah valid dengan kategori kevalidan sangat tinggi. Walaupun kevalidan media pembelajaran telah sangat tinggi, namun masih ada beberapa komponen yang harus diperbaiki.

b. Uji Praktikalitas Media Pembelajaran

Praktikalitas media pembelajaran asam basa menggunakan aplikasi android berbasis chemistry triangle dilihat dari keterpakaian produk dari hasil uji coba terbatas di lapangan menyangkut kepraktisan dan keterlaksanaan produk yang dikembangkan.

Tabel 3. Data Penilaian Praktikalitas Media Pembelajaran

\begin{tabular}{|c|c|c|c|}
\hline No. & $\begin{array}{c}\text { Data } \\
\text { Praktikalitas }\end{array}$ & $\begin{array}{c}\text { Nilai rata- } \\
\text { rata moment } \\
\text { kappa (k) }\end{array}$ & $\begin{array}{c}\text { Kategori } \\
\text { kepraktisan }\end{array}$ \\
\hline 1. & Respon Guru & 0,84 & Sangat Tinggi \\
\hline 2. & Respon Siswa & 0,88 & Sangat Tinggi \\
\hline
\end{tabular}

Penilaian praktikalitas media pembelajaran asam basa menggunakan aplikasi android berbasis chemistry triangle diperoleh sangat tinggi. Dari hasil praktikalitas tersebut, maka media pembelajaran asam basa menggunakan aplikasi android berbasis chemistry triangle ini dapat diterapkan pada proses pembelajaran di sekolah.

\section{SIMPULAN}

Berdasarkan hasil penelitian yang telah dilakukan, dapat diperoleh kesimpulan bahwa media pembelajaran asam basa menggunakan aplikasi android berbasis chemistry triangle kelas XI SMA/MA ini memiliki kategori kevalidan dan kepraktisan sangat tinggi sehingga layak digunakan dalam proses pembelajaran kimia

\section{UCAPAN TERIMAKASIH}

Penulis mengucapkan terimakasih kepada Bapak Dr. Rahadian Zainul, S.Pd, M.Si, Bapak Drs. Zul Afkar, M.S., Ibu Prof. Dr. Hj. Ellizar, M.Pd, Ibu Dra. Hj. Bayharti, M.Sc, Bapak Drs. Iswendi, MS, serta semua pihak yang telah membantu dalam penyelesaian penelitian dan penyusunan artikel ini.

\section{REFERENSI}

[1] Daryanto. 2011. Media Pembelajaran. Bandung: Satu Nusa.

[2] Sunyono. 2012. "Kajian Teoritik Model Pembelajaran Kimia Berbasis Multipel Representasi (SiMaYang) Dalam Membangun Model Mental Pebelajar". Prosiding Seminar Nasional Sains, 14 Januari 2012. Universitas Negeri Surabaya.

[3] Chittleborough, G. D. 2014. "The Development of Theoretical Framework for Understanding the Learning of Chemistry". International Journal Of Science Education. Agustus 2014. Vol 38. No. 4. hal 25-39.

[4] Talanguer, Vicente. 2010. " Macro, Submicro, and Symbolic: The Many Faces of The Chemistry “ Triplet". International Journal of Science Educatoin. Januari 2010. Vol 33. No 2. Hal 179. 195.

[5] Hamalik, Oemar. 2001. Proses BelajarMengajar. Bandung : PT. BumiAksara.

[6] Yanuariska, Anggi. 2015. "Pengembangan Media Pembelajaran Kimia Berbasis Chemistry Triangle Menggunakan Aplikasi Android Untuk Materi Elektrokimia Kelas XII SMA/MA". Skripsi. Universitas Negeri Padang.

[7] Trianto. 2010. Model Pembelajaran Terpadu. Jakarta: Bumi Aksara

[8] Boslaugh, Sarah dan Paul A. W. 2008. Statistics in a Nutshell, a desktop quick reference. Beijing, Cambridge, Famham, Köln, Sebastopol, Taipei,Tokyo: O'reilly. 